UDK $[94+930](47+57)$

Submitted: 15.04 .2020

LBC 63.3

Accepted: 05.05.2020

\title{
FINAL CHORDS OF M.N. POKROVSKY'S "BRAINCHILD": SOCIETY OF MARXIST HISTORIANS IN THE EARLY 1930s
}

\author{
Victor N. Danilov \\ N.G. Chernyshevskiy Saratov State University, Saratov, Russian Federation
}

\begin{abstract}
Introduction. The Society of Marxist Historians established in 1925 went down in the history of Soviet historiography as a militant organization that did much to combat "old school" historians, assert the monopoly position of the Marxist-Leninist methodology, and draw a party line in historical science. Methods and materials. The research is based on traditional methods of historiographical analysis. It uses materials from historical journals of the 1920s and 1930s and archival documents. Analysis. The first all-Union conference of Marxist Historians (December 28, 1928 - January 4, 1929) became the apogee in the history of the Society. In the future, despite the growth in numbers and the creation of local structures, in the conditions of the "great turning point" it loses the features of an amateur organization and a number of functions of the scientific nature. The priority is to "actively participate in the socialist construction" by deploying mass propaganda of historical knowledge and fighting "distortions of Marxism-Leninism", including in the ranks of the organization itself. The last debate and "study" of Stalin's famous letter to "Proletarian revolution" journal had a negative impact on the internal state of the Society and strengthened the distrust of the results of his work from the government. In 1931-1932, the Society management unsuccessfully tried to make its work more popular, hold a plenum and re-registered a new charter. Results. However, at that time, the Central Committee of the CPSU(b) embarked on the path of reformatting the structure of societies and unions in the country and eliminating those of them that had exhausted their mobilization potential and did not meet the new ideological course. In addition to this circumstance, the rapid curtailment of the Society of Marxist historians by the end of 1932 was influenced by the position of the leadership of the Communist Academy and the death of M.N. Pokrovsky, the undisputed leader of Soviet historians.
\end{abstract}

Key words: Society of Marxist Historians, M.N. Pokrovsky, Communist Academy, early 1930s, historiography, ideology, scientific discussion, completion of activity.

Citation. Danilov V.N. Final Chords of M.N. Pokrovsky's "Brainchild": Society of Marxist Historians in the Early 1930s. Vestnik Volgogradskogo gosudarstvennogo universiteta. Seriya 4. Istoriya. Regionovedenie. Mezhdunarodnye otnosheniya [Science Journal of Volgograd State University. History. Area Studies. International Relations], 2021, vol. 26, no. 2, pp. 143-156. (in Russian). DOI: https://doi.org/10.15688/jvolsu4.2021.2.11

УДК $[94+930](47+57)$

ББК 63.3

Дата поступления статьи: 15.04.2020

Дата принятия статьи: 05.05.2020

\section{ФИНАЛЬНЫЕ АККОРДЫ «ДЕТИЩА» М.Н. ПОКРОВСКОГО: ОБЩЕСТВО ИСТОРИКОВ-МАРКСИСТОВ В НАЧАЛЕ 1930-Х ГОДОВ}

\author{
Виктор Николаевич Данилов \\ Саратовский национальный исследовательский государственный университет им. Н.Г. Чернышевского, \\ г. Саратов, Российская Федерация
}

Аннотация. Общество историков-марксистов, созданное в 1925 г., вошло в историю советской историографии как организация воинствующего толка, много сделавшая для борьбы с историками «старой школы», утверждения монопольного положения марксистско-ленинской методологии и проведения партийной линии в исторической науке. Первая всесоюзная конференция историков-марксистов (28 декабря 1928 г. 4 января 1929 г.) стала апогеем в истории Общества. В дальнейшем, несмотря на рост численного состава и создание местных структур, в условиях «великого перелома» оно утрачивает черты самодеятельной органи- 
зации и ряд функций научного характера. Приоритетной становится задача «активного участия в социалистическом строительстве» путем развертывания массовой пропаганды исторических знаний и борьбы с «искажениями марксизма-ленинизма», в том числе в рядах самой организации. Последние дискуссии и «проработка» известного письма Сталина в редакцию журнала «Пролетарская революция» негативно повлияли на внутреннее состояние Общества и усилили недоверие к результатам его работы со стороны власти. В 19311932 гг. руководство Общества безуспешно пыталось сделать его работу более популярной, провести пленум и перерегистрировать новый устав. Однако в это время ЦК ВКП(б) встал на путь переформатирования структуры обществ и союзов в стране и ликвидации тех из них, которые исчерпали свой мобилизационный потенциал и не отвечают новому идеологическому курсу. Помимо этого обстоятельства, на быстрое свертывание к концу 1932 г. деятельности Общества историков-марксистов повлияли позиция руководства Комакадемии и смерть М.Н. Покровского, безусловного лидера советских историков.

Ключевые слова: Общество историков-марксистов, М.Н. Покровский, Комакадемия, начало 1930-х гг, историография, идеология, научная дискуссия, завершение деятельности.

Цитирование. Данилов В. Н. Финальные аккорды «детища» М.Н. Покровского: общество историковмарксистов в начале 1930-х годов // Вестник Волгоградского государственного университета. Серия 4, История. Регионоведение. Международные отношения. - 2021. - Т. 26, № 2. - C. 143-156. - DOI: https:// doi.org/10.15688/jvolsu4.2021.2.11

Введение. Общество историков-марксистов - одно из наиболее известных научных объединений в отечественной историографии, во многом способствовавшее формированию во второй половине 1920-х - начале 1930-х гг. облика советской исторической науки. В конфронтации с традицией «старой школы» оно решало практические задачи внедрения марксистского метода и основанных на нем конкретно-исторических схем. В значительной мере деятельность Общества строилась вокруг фигуры М.Н. Покровского (1868-1932), который по праву считал его своим «детищем». По своей сути Общество было не только научным явлением, но и фактором политической жизни того времени, «одним из партийных отрядов на идеологическом участке классовой борьбы». Поэтому всякие изменения на этом «участке» неминуемо должны были отражаться и на состоянии Общества, приведя в конечном итоге к его упразднению.

В советской историографии прекращение деятельности Общества историков-марксистов связывали с произошедшей в середине 1930-х гг. консолидацией советских историков на единой марксистско-ленинской методологической основе [13, с. 22]. Считалось, что «проходивший в 20-х - начале $30-x$ гг. процесс поиска завершился утверждением единых, наиболее целесообразных форм организации научно-исследовательской работы» [18, с. 110]. Позже закрытие в это время большого числа обществ и союзов стали объяснять издержка- ми «культа личности Сталина» [21, с. 14]. В этой связи Т.П. Коржихина отмечала, что, признавая решающую роль в этом процессе административно-командной системы, не следует отказываться от выявления причин, приводивших к ликвидации общественных организаций в каждом конкретном случае [20, с. 265-266]. Омский историк О.В. Метель полагает, что окончание «культурной революции» привело «к постепенному закрытию особых «коммунистических» центров, на которые ранее большевиками возлагались большие надежды», но в новых условиях не способные больше работать [24, с. 217]. В свое время нами была высказана точка зрения о том, что свертывание деятельности Общества историков-марксистов было обусловлено смертью его бессменного лидера М.Н. Покровского [10, с. 103]. Отмечая и сейчас этот фактор существенным в судьбе Общества, мы вовсе не отказываемся от выяснения всех обстоятельств, приведших к подобному финалу, чему и посвящена данная статья.

Методы и материалы. Как всякое историографическое исследование, работа основывается на принципе историзма, который предполагает, что каждый историографический факт анализируется в процессе возникновения, становления и развития, а события исторической науки изучаются в тесной связи с условиями их появления. Стремление к непредвзятому анализу источников может быть рассмотрено и в координатах принципа объективности. Важнейшее значение для нас име- 
ет использование сравнительно-исторического метода, позволяющего проследить качественные изменения в историографических явлениях на различных этапах. На изучение отдельных историографических ситуаций ориентирован метод конкретного анализа.

Исследование базируется на материалах, отражающих историю Общества историков-марксистов, одни из них публиковались в периодических изданиях организации - журналах «Историк-марксист» и «Борьба классов», а другие - отложились в архивных фондах Общества (Ф. 377) и Комакадемии (Ф. 350), которые хранятся в Архиве Российской академии наук.

Анализ. Рубежным событием для Общества стало проведение Первой всесоюзной конференции историков-марксистов (28 декабря 1928 г. - 4 января 1929 г.), после чего оно стало утрачивать черты самодеятельной организации и ряд функций научного характера. Неизменным остался только рост его состава. Если при создании в 1925 г. в него вошло 40 человек, то уже на 1 января 1929 г. в Обществе состояло 345 человек действительных членов и членов-корреспондентов [12, c. 218], а в середине 1932 г. оно насчитывало почти тысячу человек [9, л. 22]. К тому времени Общество включало в себя, помимо историков из Москвы (около половины всего состава), 29 местных и республиканских отделений практически по всему Союзу. При вузах, комвузах, музеях и архивах, а также некоторых предприятиях были созданы ячейки содействия. Вместе с тем Обществу не удалось выйти за узкопартийные рамки. «Думали, - говорил М.Н. Покровский, - что около небольшого, сравнительно, партийного ядра сгруппируется большое количество беспартийных историков, тяготеющих к нам» [36, c. 3]. Но получилось обратное: три четверти организации составляли члены ВКП(б). Безусловно, требование наличия печатных работ или самостоятельного преподавания в вузе для действительных членов служило способом поддержания научного уровня Общества, но оно же потом стало поводом для обвинений в корпоративной замкнутости. Не ясной была ситуация с Украинским обществом историков-марксистов. Даже в 1931 г. признавалось, что с ним «существовала только ин- формационная связь» и «историки-марксистыукраинцы находятся на отлете» [26, с. 136]. Это, конечно, снижало реальный статус Общества, считавшегося с 1930 г. организацией всесоюзной.

Следование классово-партийному подходу неизбежно вело советских историков к ограничению проблематики исследовательской работы. «У нас не только свой метод, но и своя тематика и свои проблемы», - отмечалось в одном из программных документов Общества историков-марксистов [25, с. 15]. Главным образом разрабатывалась социально-экономическая и революционная проблематика, а основной формой работы долгое время являлось заслушивание докладов на заседаниях секций, многие из которых затем публиковались в журнале «Историк-марксист». При этом число докладов постоянно увеличивалось: если в 1925 г. было заслушано всего 4 доклада, то в 1926 г. - уже 11, в 1927 г. 16, а в 1928 г. выросло до 31 [27, с. 203]. Рекордное число докладов было сделано в 1930 г. -87 [19, с. 109].

Изначально приоритетной для Общества историков-марксистов считалась задача «борьбы с извращениями истории буржуазной наукой», но активное наступление на историков «старой школы» началось весной 1928 г. и связывается современными историками с необходимостью реакции на «Шахтинское дело» [3, с. 80]. Инициатива в этом деле исходила от самого М.Н. Покровского, который в статье «“Новые” течения в русской исторической литературе» поставил в вину Д.М. Петрушевскому «протаскивание идей неокантианства», а Е.В. Тарле- -ззатушевывание объективного хода европейской истории к социалистической революции» [35]. Вскоре за ним последовали и его ученики, проведя обличительный диспут по книге Петрушевского [11].

Следующим этапом в этой борьбе стала реорганизация Института истории РАНИОН, в котором совместно работали историки-марксисты и историки «старой школы». В ноябре 1929 г. он был включен в Коммунистическую академию, что привело не только к кадровым изменениям, но и направленности его исследований. Свертывалась традиционная для русской исторической науки тематика по хроно- 
логическим периодам, а структура Института почти полностью стала повторять структуру самого Общества историков-марксистов, функции которого подверглись корректировке. Теперь оно должно было вести «работу по координации работ отдельных исторических институтов, ...по популяризации исторических знаний, наблюдению за постановкой исторической работы на местах и т. п., перенося, однако, работу по систематической научноисследовательской работе в Институт истории» [23, с. 429-430].

Заключительным актом наступления на историков «старой школы» стало печально знаменитое «Академическое дело». Хотя Общество историков-марксистов и не было его инициатором, оно, тем не менее, испытывало немалое удовлетворение от учиненного погрома «буржуазной науки». Выступая на общем собрании Общества 19 марта 1930 г., М.Н. Покровский заявил, что «эти люди настолько разоблачены и пригвождены, что считаться с ними как идейными противниками, кому же придет в голову сейчас» [36, с. 10].

В условиях «великого перелома» все больше происходило переориентирование Общества историков-марксистов на сопровождение текущей политики партии. В резолюции упомянутого собрания в качестве приоритетной для Общества была обозначена задача «принять самое энергичное участие в работе социалистической реконструкции, подготавливая в темпе более быстром, чем все виданные до сих пор, новые и гораздо более широкие кадры работников данного участка культурно-просветительного фронта и способствуя историческим анализом прояснению сознания всех работников этого фронта и всех масс трудящихся» [41, с. 165]. Другой задачей Общества, в духе сталинских указаний о развертывании самокритики, должна была стать борьба с «пережитками буржуазных концепций» в собственной среде [41, с. 166].

Вскоре руководство Общества рапортовало о том, что «провело успешную борьбу против оживления меньшевистских, механистических концепций Богданова и Рожкова в книге т. Дубровского об «Азиатском способе производства», искажающем учение Маркса Ленина об общественно-экономических формациях. Энергичный отпор был дан правооп- портунистическому выступлению т. Теодоровича, изобразившего в дискуссии о «Народной Воле» народников предшественниками большевизма и тем затушевавшего мелкобуржуазную сущность народничества» [19, c. 108]. «Серьезные ошибки» были обнаружены также в трудах обвиненного в национально-демократическом уклоне ведущего украинского историка-марксиста М.И. Яворского.

Тем не менее в 1930 г. еще самооценка положения дел в Обществе была в целом положительной: «рядом с нашими достижениями приходится отметить некоторые дефекты», - говорил М.Н. Покровский [36, с. 11]. Но уже через год, после XVI съезда ВКП(б), в тезисах комфракции совета Общества, принятых 6 февраля 1931 г., заявлялось, что «практическая работа по своим темпам не отвечает еще тем требованиям, какие вытекают из общего положения нашей страны и задач марксистско-ленинской науки в период завершения фундамента социалистического хозяйства». Причиной этой медлительности называлось то, что «само Общество и планы его работы засорены людьми и темами, которым в боевом Обществе марксистов-ленинцев нет места» $[25$, с. 12,14$]$.

В это время меняется и партийно-государственная политика по отношению к общественным организациям. В январе 1931 г. в ЦК ВКП(б) был создан отдел культуры и пропаганды (Культпроп), на который возлагалась функция идеологического контроля в сфере науки, литературы и искусства. 15 марта 1931 г. Политбюро ЦК ВКП(б) выносит постановление по докладу президиума Коммунистической академии, которым существенно ограничило сферу деятельности научных обществ, состоявших при Комакадемии. На них теперь возлагалась только организация «массовой работы, дело пропаганды марксизма и ленинизма в своей области, популяризация научных достижений и работа с научными кадрами, особенно в нацреспубликах и отдаленных областяХ» [37, с. 4].

Осложнили работу Общества историковмарксистов и факторы внутреннего порядка. В первую очередь то обстоятельство, что в 1929 г. у М.Н. Покровского диагностировали рак, и в последующем он уже не мог, как раньше, плотно заниматься делами Общества ис- 
ториков-марксистов, в последние месяцы жизни вообще не имел связи с ним. Заседание комфракции 6 февраля 1931 г. было последним публичным мероприятием Общества, на котором Покровский выступал с докладом. Нарушила стабильность в работе общества и смена ученого секретаря. В конце 1930 г. ЦК ВКП(б) принял решение направить П.О. Горина (Коляда), занимавшего эту должность с момента основания Общества, в Минск в качестве Президента Белорусской академии наук. Покровский, возражая против этого перевода, направил письмо на имя секретаря ЦК В.М. Молотова, в котором указал, что «это катастрофа для Общества и риск его распада» [1, с. 4]. Только 11 мая 1931 г. президиум Комакадемии утвердил на этом посту Х.Г. Лурье [7, с. 126] - молодого историка, несомненно обладавшую организаторскими способностями, но не имевшую необходимого научного и политического авторитета. Вскоре по личным обстоятельствам она вынуждена была сделать перерыв в работе, и с июля по ноябрь 1931 г. временно исполнял должность ученого секретаря И.Л. Татаров (Каган) - известный общественный деятель, участник многих исторических дискуссий и ответственный секретарь журнала «Историк-марксист» [42, л. 9]. В начале ноября Х.Г. Лурье снова приступила к своим обязанностям, а после смерти 10 апреля 1932 г. М.Н. Покровского и до прекращения деятельности Общества была главным его должностным лицом.

В феврале - мае 1931 г. в Обществе историков-марксистов состоялась последняя дискуссия, которая была посвящена положению в области изучения истории Запада. В связи с кризисом в ведущих капиталистических странах и якобы обозначившейся революционной перспективой ей придавалось практически политическое значение. Вместе с тем дискуссия выявила и изменение нравственной атмосферы в Обществе историковмарксистов. Опасения быть обвиненными в недостаточной бдительности по отношению к классовым врагам и их пособникам, в отсутствии должной самокритики заставляли советских историков, особенно молодых, выискивать «ошибки» и всякого рода «искажения марксизма-ленинизма» в трудах своих коллег, не взирая на их заслуги. Даже руково- дитель Культпропа ЦК ВКП(б) А.И. Стецкий был вынужден отметить явные «перегибы» в ходе этой дискуссии. «Отдельные товарищи, говорил он на партийном собрании Комакадемии 28 марта 1931 г., - выступали с такого рода положениями, что на фронте западной истории у нас политическое неблагополучие, что неправильная генеральная линия работы О-ва историков-марксистов и т. д. и т. п., что необходимо поставить вопрос о руководстве этим самым фронтом западной истории и т. д. Пытались зачеркнуть все ценное, что было сделано на этом фронте западной истории. Совершенно естественно, что такого рода перехлестываниям необходимо давать самый решительный отпор» [45, с. 16]. 16 июня 1931 г. М.Н. Покровский, ознакомившись с проектом резолюции по итогам дискуссии, направил в Президиум Комакадемии письмо, в котором «решительным образом» протестовал против возведения «на известных и занимающих руководящие теоретические посты старых товарищей (имелись в виду Ротштейн, Лукин и Волгин. - В. Д.) чудовищных теоретических обвинений без малейшей попытки эти обвинения обосновать» [6, л. 20].

Указание ЦК ВКП(б) заниматься главным образом массовой работой ставило руководство Общества историков-марксистов в затруднительное положение относительно дальнейшей деятельности секций в столице и отделений в провинции. Лишь осенью 1931 г. оно определилось с планами постановки докладов и консультаций на предприятиях и ведущих стройках пятилетки. Новые возможности для активизации работы открывались перед Обществом в связи с решениями ЦК ВКП(б) об издании «Истории гражданской войны» и «Истории фабрик и заводов». При президиуме совета была образована комиссия содействия написанию истории гражданской войны. Такие же комиссии были созданы в отделениях Общества на местах. Работа по изучению истории фабрик и заводов была возложена на секцию истории пролетариата, а основными исполнителями по подбору и систематизации материала для написания монографий должны были стать ячейки содействия. Как говорилось в кратком обзоре деятельности Общества историков-марксистов, «теперь не может уже быть разговоров о неопределенности содержания» их 
работы, поскольку она «не является надуманным, а создается самой жизнью» [17, с. 159]. Вскоре в новом массовом журнале Общества «Борьба классов» стали публиковаться очерки, сообщения и воспоминания, касавшиеся истории гражданской войны и ряда заводов и фабрик.

Но этот настрой на реальную исследовательскую и популяризаторскую работу, хотя и по ограниченной тематике, уже в конце октябре 1931 г. был прерван публикацией письма И.В. Сталина в редакцию журнала «Пролетарская революция» «О некоторых вопроcax истории большевизма». Политический смысл этого письма, характер отклика на него, воздействие на науку и судьбы историков, все это достаточно подробно рассмотрено в работах последних десятилетий $[2 ; 14 ; 22]$. Отметим лишь несколько важных для нашего исследования моментов. Прежде всего заслуживает внимания тот факт, что именно Общество историков-марксистов оказалось в центре кампании по обсуждению сталинского письма. Трижды в Москве комфракция Общества $(11,14$ и 18 ноября 1931 г.) собиралась по этому вопросу на свои заседания, в которых приняло участие несколько сот человек, а местные отделения разворачивали эту работу в провинции. Совершенно очевидно также, что, расширяя в ходе «проработки» масштабы выявляемой «троцкистской контрабанды» и «фальсификации» истории партии, о чем говорилось в сталинском письме, и круг лиц в них повинных, кроме Слуцкого и Волосевича (Слепков, Рахметов, Миронов, Альтер, Бернштейн, Минц, Кин, Пионтковский и др.), советские историки давали повод власти для сомнений в своей благонадежности. Более того, неуклюжий содоклад (доклад делал член ЦК ВКП(б) В.Г. Кнорин) на первом заседании комфракции Общества его ученого секретаря Х.Г. Лурье вообще обесценивал всю предшествующую работу организации и наводил на мысль о научной несостоятельности советских историков. В частности, она заявила, что до появления письма Сталина историки вообще не имели методологии и не знали, что такое теория и практика [14, с. 290].

Весной 1932 г., когда несколько спала суета вокруг сталинского письма, возобновилась кампания по перестройке деятельности
Общества историков-марксистов, как это было определено еще на заседании комфракции 6 февраля 1931 года. Перестройка форм и методов работы, по замыслу руководства, должна была повысить ее качество, ввести плановое начало, методы соцсоревнования и ударничества в работу секций, отделений и ячеек содействия для того, «чтобы обеспечить неустанную борьбу за генеральную линию партии, против оппортунистических искажений в исторической литературе, борьбу против буржуазных теорий за большевистскую партийность в исторической науке» [17, c. 159]. С этой целью была создана специальная бригада, которая провела в апреле несколько своих заседаний, где был высказан ряд предложений по изменению структуры Общества. На заседании «бригады по перестройке работы О-ва» был поставлен также вопрос: должно ли общество в дальнейшем существовать как всесоюзная организация или должна быть организована федерация республиканских обществ? «Вопрос, - сказала Лурье, - который подлежит решению ЦК, но по которому мы должны высказать свое мнение» $[38$, л. 1]. Предложение о федеративном устройстве по своей сути было запоздалой реакцией на «самостийность» Украинского общества историков-марксистов. Окончательно вопрос о перестройке деятельности, как предполагалось, должен был решить пленум Общества, безуспешные попытки созвать который растянулись на целых полтора года.

Еще в начале 1931 г. прозвучало предложение провести в конце 1931 г. совещание совета, а затем Вторую всесоюзную конференцию историков-марксистов [25, с. 16]. 5 мая 1931 г. президиум совета Общества назвал в качестве даты проведения конференции декабрь 1931 г., а вместо совещания постановил созвать расширенный пленум совета с участием представителей с мест и членов московского общества, на котором заслушать доклады М.Н. Покровского о работе Общества и задачах исторической науки в реконструктивный период и Х.Г. Лурье о реорганизации Общества историков-марксистов во всесоюзную организацию [4, с. 135]. В результате согласований с Культпропом ЦК ВКП(б) решено было ограничиться проведением пленума (без слова совета. - В. Д.) в ноябре 
1931 г., о чем президиум совета проинформировал отделения и членов Общества [17, c. 159]. Но появление в октябре письма Сталина и ажиотаж вокруг него нарушили эти планы. Возвратиться к вопросу о проведении пленума смогли только весной 1932 года.

27 марта 1932 г. президиум совета Общества на своем заседании определил в качестве даты проведения пленума 20 мая 1932 г., а для подготовки к нему создал организационную комиссию под председательством директора Института истории Н.М. Лукина. В постановлении президиума было также записано: «провести в апреле месяце ряд отчетных заседаний, посвященных подведению итогов работы общества с постановкой ряда сообщений президиума О-ва и отдельных местных организаций» [39, л. 7]. Таким образом, по формату подготовки пленум ничем не отличался от конференции, к тому же его планировалось провести в течение трех дней. На следующем заседании президиума 20 апреля 1932 г. была определена повестка пленума, включавшая в себя отчетный доклад президиума Общества (Х.Г. Лурье), доклады «Покровский как историк-марксист» (А.И. Стецкий, прений не предполагалось), «История гражданской войны» (А.С. Бубнов), «Ленин и большевики во II Интернационале» (В.Г. Кнорин). По требованию Культпропа выступающие должны были заранее представить тезисы своих докладов с последующим их обсуждением в оргкомитете. Кроме того, намечалось создать бригады «разоблачительной критической и самокритической работы» по историческим журналам и отдельным историкам (Ванаг, Горин, Пионтковский, Шляпников и др.), результаты которой предполагалось доложить на пленуме [16, л. 2]. Журнал «Борьба классов» опубликовал обращение ко всем отделениям Общества с просьбой прислать информационные материалы, необходимые для подготовки к пленуму [8, с. 136]. Вскоре, однако, выяснилось, что в столь короткий срок нет возможности выполнить все условия подготовки и проведения пленума, и президиум перенес его на июнь 1932 года.

Но и этот срок проведения пленума оказался не реальным. В конце мая 1932 г. ученый секретарь Ленинградского отделения Общества А.Г. Пригожин направил в президиум письмо, в котором содержалась просьба перенести пленум теперь уже на осень, мотивируя тем, что «до сего времени на местах не известны тезисы докладчиков, не говоря уже о тезисах отчетного доклада Общества; июнь месяц, кроме того, является концом учебного года, когда все историки Ленинграда должны закончить свои обязательства по учебникам и вследствие этого не сумеют отдать подготовке пленума должного времени» [34, л. 75]. На этом же настаивали и основные докладчики. И вот на заседании президиума Общества 7 июня Лурье доложила о том, что «по согласованию с Культпропом ЦК созыв пленума историков-марксистов перенесен на 20 сентября с/года». Она также уведомила, что Культпроп внес изменения в порядок дня: «положение и задачи исторического фронта будут рассмотрены в отдельных исторических участках, при обсуждении научных докладов», число которых будет включен еще и доклад Н.М. Лукина «Основные проблемы рабочего движения эпохи империализма» [40, л. 1]. Отсутствие отчетного доклада вызвало возражение со стороны ряда членов президиума, считавших, что было бы полезным обобщить опыт деятельности общества, как бы в дальнейшем не сложилась его судьба. Но, поскольку здесь они не могли что-либо изменить, сошлись на том, чтобы «просить ЦК поставить на пленуме информационное сообщение об организационных формах работы историков-марксистов» $[40$, л. 2$]$. По результатам этого заседания в отделения и ячейки содействия Общества было направлено информационное письмо, в котором содержалось указание оперативно сообщить имена выступающих и их темы, а также «установить системы проверки, чтобы представленная отсрочка созыва пленума была бы действительно использована для подготовки к выступлению» [33, л. 15]. Поступавшие летом 1932 г. в президиум сообщения говорили о том, что значительная часть членов Общества была настроена на безусловное проведение пленума.

Тем не менее подготовка к пленуму встречала все новые препятствия. Ни один из основных докладчиков летом 1932 г. так и не представил тезисы. Более того, 29 июля В.Г. Кнорин направил в президиум Общества собственноручную записку, в которой сооб- 
щал, что «целый ряд обстоятельств на международной арене сейчас требует всех моих сил для работы в КИ, поэтому я готовить доклад не могу и должен от него отказаться, тем более, что сроки Вашего пленума очень близки к срокам некоторых интернациональных совещаний» [29, л. 185]. В это же время стали приходить с мест письма с просьбами снова перенести срок проведения пленума на более позднее время. Теперь эти просьбы уже мотивировались тем, что почти весь актив отделений занят работой по подготовке к пятнадцатилетнему юбилею Октябрьской революции и «сейчас очень трудно отрывать товарищей для поездки в Москву» [32, л. 193]. Становилось все более очевидным, что пленуму так и не суждено будет состояться, поскольку на повестке дня уже стоял вопрос о дальнейшем существовании самого Общества историков-марксистов.

Впервые прямым текстом о ликвидации Общества, как «вопросе уже предрешенном», было заявлено Н.М. Лукиным на заседании президиума совета Общества 7 июня 1932 г. [40, л. 2]. Дело в том, что в это время в ЦК ВКП(б) стали пересматривать отношение к существовавшей системе общественных организаций, созданным на классово-идеологической основе. 23 апреля 1932 г. выходит знаменитое постановление Политбюро «О перестройке литературно-художественных организаций», в котором говорилось об опасности превращения такого рода организаций из средства мобилизации интеллигенции «вокруг задач социалистического строительства в средство культивирования кружковой замкнутости, отрыва от политических задач современности» [5, с. 173]. Хотя данное постановление и не касалось непосредственно научных обществ, но оно методологически встраивало и их в эту политическую линию. Соответствующим секторам Культпропа ЦК ВКП(б) было поручено проанализировать деятельность обществ, состоящих при Комакадемии, высказать рекомендации по их перестройке. С этой целью 15 мая 1932 г. в Комакадемии было созвано совещание с участием представителей Культпропа, на котором руководители обществ выступали с анализом деятельности своих организаций и предложениями по дальнейшей их деятельности.
Выступление Х.Г. Лурье было выдержано в духе самокритики по всем трем основным направлениям деятельности Общества историков-марксистов - научной, организационной и массовой. Характеризуя в целом положение в Обществе, она констатировала, «что то резкое отставание от задач социалистического строительства, которое отмечено тов. Сталиным, нами в настоящее время не ликвидировано», и не только по причине того, что из президиума выбыло три четверти членов и существует параллелизм секций, но и потому, что в таком виде, как оно есть, Общество «не рационально, оно не выполняет тех задач, которые перед ним ставятся». Отсюда, по ее мнению, нужна более массовая организация, поскольку перед историками стоят новые задачи в связи с введением истории в среднюю школу и написанием трудов, определенных постановлениями ЦК партии [44, л. 23-24]. Примерно в таком же духе высказывались и представители других научных обществ.

Однако, похоже, партийные функционеры склонялись к более радикальным решениям, считая, что одни общества уже исчерпали свой мобилизационный потенциал, и с задачами, которые они выполняли, могут справиться государственные учреждения, а существование других - служит препятствием проведению государственной научной политики. Не случайно, что со стороны представителя Культпропа Ф.А. Горохова (до этого замдиректора института философии Комакадемии) вопрос, заданный Лурье, звучал так: «Считаете ли вы нормальным, что в обществе историков-марксистов развертывается научная работа - не в смысле параллелизма, а в смысле разработки проблем» [44, л. 24 об.]. Но не столько покушение обществ на прерогативы научных институтов волновало партийные органы в данном случае, сколько пресловутая «замкнутость». Тот же Горохов заявил на совещании, что в некоторых обществах «такое же положение, которое сложилось в РАППе... РАПП оказался довольно замкнутой организаций», «эту замкнутость, известный элемент сектантства» усилил, по его мнению, «строгий подход к определению членства в обществе» [44, л. 26-27]. А это уже был явный намек в том числе и на Общество историков- 
марксистов, где сохранилась зависимость членства от наличия печатных трудов, что сдерживало его массовость.

Перспектива ликвидации научных обществ, состоявших при Комакадемии, потребовала решения ряда проблем организационно-материального характера, в частности, определения порядка финансирования массовой работы институтов, которую ранее вели общества. С этой целью 31 августа 1932 г. в президиуме Комакадемии состоялось специальное совещание, предписывавшее каждому институту оперативно определиться со сметами расходов по массовой работе (лекции, проведение конференций, издание популярной литературы, выезды на места), которую они целиком будут перенимать от обществ. В каждом институте в штат вводилась должность заведующего массовой работой. Единственное, что беспокоило в этой связи участников совещания судьба ячеек содействия обществам. По этому поводу представитель Института советского строительства и права говорил следующее: «Если будут ликвидированы о-ва, создается некоторая трудность по части организации ячеек на местах, вне Москвы. Группы содействия институтам - само по себе будет не столь благозвучны, чтобы вокруг этого лозунга объединились местные работники. Сейчас под именем общества, и то очень туго, а когда это будет группа содействия институту, это будет еще хуже. Вопрос не только в самом названии, но здесь была форма, которая позволяла организовать ячейки вне Москвы. С точки зрения Москвы ликвидация о-в имеет плюсы, по крайней мере вся работа у нас проводилась за счет узкого круга лиц, тех же руководящих постоянных работников ин-та и поэтому привлечение к декадникам, к работе - лиц со стороны у нас не было и ликвидация обществ ничего страшного не несет. Но что касается связи с местами, - то будут некоторые осложнения〉 [43, л. 9].

Осенью 1932 г. деятельность Общества историков-марксистов стала сворачиваться, особенно в Москве. Хотя его члены сделали несколько докладов на собраниях и заседаниях, посвященных 15-летию Октябрьской революции, продолжалась работа по собиранию материала для «Истории гражданской войны» и монографий по истории фабрик и заводов.
По некоторым секциям было заслушано несколько докладов: А.М. Панкратовой, Н.М. Майорского, В.П. Потемкина и др. Время от времени в крайне малочисленном составе собирался на свои заседания президиум совета Общества. Последний его протокол датирован 29 декабря 1932 года.

Руководство Общества попыталось также перерегистрировать устав, что было вызвано выходом 10 июля 1932 г. нового Положения о добровольных обществах и союзах. Введение этого положения (третьего по счету) объяснялось поворотом деятельности добровольных обществ и союзов в направлении «усиления их участия в социалистическом строительстве». Тем самым власть стремилась устранить считавшимися недостатками в работе научных обществ: академизм, корпоративность и отрыв от нужд производства. В самом конце октября 1932 г. ученый секретарь Общества историков-марксистов получил письмо из Комитета по заведыванию учеными и учебными заведениями ЦИК СССР (Комакадемия находилась при ЦИК), в котором сообщалось, что представленный проект устава «не соответствует требованиям нового закона о добровольных обществах» и они ждут представителя Общества для «переговоров о дальнейшем направлении этого вопроса» [30, л. 6]. Мы не располагаем какимилибо сведениями о дальнейшей судьбе проекта устава Общества. По всей видимости, он застрял где-то в инстанциях, с которыми шло согласование, и не выносился на утверждение ВЦИК.

В этот период руководство Общества историков-марксистов фактически потеряло связь с местными отделениями, о чем говорит письмо от 28 декабря 1932 г. из Новосибирска, содержавшее такие строки: «Бюро Западно-Сибирского отделения О-ва историков-марксистов с удивлением констатирует, что за последние 4-5 месяцев Совет общества историков-марксистов не чем не дает о себе знать на места. Нет никаких сведений о том, как протекает работа Совета, что делает и предполагает делать. Нет сведений и о предполагавшемся, сначала в мае, а затем в сентябре, созыве пленума Совета общества с присутствием представителей с мест. Чем объясняется это молчание совета, неизвестно». 
Далее коллеги из Сибири просили прислать информацию о положении дел в обществе, о планах и намерениях дальнейшего развития деятельности общества [28, л. 29].

Никаких официальных решений о ликвидации или самоликвидации Общества историков-марксистов не принималось, и даже, по всей видимости, уведомлений о прекращении деятельности не направлялось в правительственные учреждения. Об этом, в частности, свидетельствует тот факт, что 15 января 1933 г. Комитет по заведыванию учеными и учебными заведениями ЦИК СССР затребовал в срочном порядке от Общества доклад о работе за период 1931-1933 гг. [31, л. 32]. Общество историков-марксистов прекращало свою работу в конце 1932 г., если можно так сказать, явочным порядком. В последнем выпуске (№ 11-12) за 1932 г. журнала «Борьба классов», подписанном 10 декабря, было снято упоминание о принадлежности его Обществу историков-марксистов, и теперь он стал просто «историческим массовым ежемесячным журналом». Однако местные отделения и ячейки содействия Обществу еще некоторое время продолжали действовать. Например, тот же журнал «Борьба классов» сообщал о том, что ячейка содействия Первого МГУ в феврале - марте 1933 г. приняла активное участие в мероприятиях, посвященных 150-летию смерти К. Маркса, с докладами выступили известные историки Бантке, Ерусалимский и др. [15, c. 119]. Педагог из Казани Р. Тагиров в 1934 г. предлагал редакции журнала для его популяризации организовать на базе «местных филиалов» Общества историков-марксистов совещания, на которых обсудить публикуемые в нем материалы [46, с. 102].

Результаты. Совершенно очевидно, что в условиях отсутствия методологического плюрализма и установления полного административного контроля в исторической науке мобилизационный потенциал Общества историков-марксистов оказывался исчерпанным. Его функции с большей эффективностью могли уже выполнять непосредственно государственные учреждения исторического профиля. Возможно, что, проживи несколько лет М.Н. Покровский, Общество историков-марксистов могло бы просуществовать еще какое-то время, как это было с Обществом пе- дагогов-марксистов, которое возглавляла Н.К. Крупская, прекратившим деятельность в 1935 году. Но так или иначе время чрезвычайных форм и методов подготовки кадров и организации научной и пропагандистской работы, рожденных революцией, в области истории к середине 1930-х гг. закончилось.

\section{СПИСОК ЛИТЕРАТУРЫ}

1. Академик П.О. Горин. Документы и материалы / сост. Н. В. Токарев. - Минск : Белоруская навука, 2011. -347 c.

2. Алаторцева, А. И. Советская историческая наука на переломе 20-30-х годов / А. И. Алаторцева // История и сталинизм / сост. А. Н. Мерцалов. М. : Политиздат, 1991. - С. 248-283.

3. Артизов, А. Н. Покровский: финал карьеры - успех или поражение? / А. Н. Артизов // Отечественная история. - 1998. - № 1. - С. 77-96.

4. В обществе историков-марксистов // Борьба классов. - 1931. - № 2. - С. 135.

5. Власть и художественная интеллигенция. Документы ЦК РКП(б) - ВКП(б), ВЧК - ОГПУ НКВД о культурной политике. 1917-1953 / сост. А. Н. Артизов, О. В. Наумов ; под ред. А. Н. Яковлева. - М. : Международный фонд «Демократия», 1999. $-868 \mathrm{c}$.

6. В президиум Коммунистической академии. Письмо М.Н. Покровского // Архив Российской академии наук (АРАН). - Ф. 377. - Оп. 1. - Д. 261. Л. 20-20 об.

7. В президиуме Комакадемии // Вестник Коммунистической академии. - 1931. - № 5-6. C. $126-127$.

8. Всем отделениям общества историков-марксистов // Борьба классов. - 1932. - № 2-3. - С. 136.

9. Выступление Х.Г. Лурье на совещании обществ, состоящих при Комакадемии 5 мая 1932 г. // АРАН. - Ф. 350. - Оп. 1. - Д. 748. - Л. 18-22.

10. Данилов, В. Н. Общество историков-марксистов и историки «старой школы» / В. Н. Данилов // История и историческая память : межвуз. сб. науч. тр. - Саратов : Изд-во Сарат. гос. ун-та, 2016. Вып. 13/14. - С. 93-103.

11. Диспут о книге Д.М. Петрушевского : (О некоторых предрассудках и суевериях в исторической науке) // Историк-марксист. - 1928. - № 8. C. 79-116.

12. Доклад Горина П.О. на I Всесоюзной конференции историков-марксистов // Историк-марксист. - 1929. - № 11. - С. 218-228.

13. Дорошенко, В. А. Образование и основные этапы деятельности Общества историков-мар- 
ксистов (1925-1932 гг.) / В. А. Дорошенко // Вестник Московского университета. Серия IX, История. 1966. - № 3. - С. 10-22.

14. Дунаевский, В. А. О письме Сталина в редакцию журнала «Пролетарская революция» и его воздействие на науку и судьбы людей / В. А. Дунаевский // История и сталинизм / сост. А. Н. Мерцалов. М. : Политиздат, 1991. - С. 284-297.

15. Жемчужина, Л. Как прошел в Москве юбилей Карла Маркса / Л. Жемчужина // Борьба классов. - 1933. - № 5. - С. 119-120.

16. Заседание оргкомитета по созыву пленума О-ва историков-марксистов от 20 апреля 1932 г. // АРАН. - Ф. 377. - ОП. 1. - Д. 251. - Л. 1-2.

17. Захарова, М. В обществе историков-марксистов / М. В. Захарова // Борьба классов. - 1931. № 6-7.- С. 159.

18. Историография истории СССР (эпоха социализма) / под ред. И. И. Минца. - М. : Высш. шк., 1982. $-336 \mathrm{c}$.

19. Как работает общество историков-марксистов // Борьба классов. - 1931. - № 1. - С. 108-110.

20. Коржихина, Т. П. Извольте быть благонадежны! / Т. П. Коржихина - М. : Изд-во Рос. гос. гуманит. ун-та, 1997. - 372 с.

21. Куйпайгородская, А. П. Добровольные общества Петрограда-Ленинграда в 1917-1937 гг. (тенденции развития) / А. П. Куйпайгородская, Н. Б. Лебина // Добровольные общества в Петрограде-Ленинграде в 1917-1937 гг. - Л. : Наука : Ленингр. отдние, 1989. - С. 5-17.

22. Макаренко, П. В. Письмо Сталина в редакцию журнала «Пролетарская революция» и его последствия для исторической науки / П. В. Макаренко // Актуальные проблемы социально-гуманитарных наук : межвуз. сб. науч. тр. / под ред. проф. И. М. Чвикалова. - Воронеж : Изд-во Воронеж. гос. лесотех. акад., 1997. - С. 45-47.

23. Метель, О.В.Институт истории Коммунистической академии в отражении документальных свидетельств / О. В. Метель // Мир историка : историогр. сб. - Омск : Изд-во Ом. гос. ун-та, 2017. C. 419-430.

24. Метель, О. В. Создание сети региональных отделений Общества историков-марксистов в 19301932 гг. / О. В. Метель // Magistra Vitae : электрон. журн. по ист. наукам и археологии. - 2018. - № 1. C. 213-219.

25. О задачах марксистской исторической науки в реконструктивный период. Тезисы фракции совета Общества историков-марксистов // Историкмарксист. - 1931. - № 21. - С. 8-17.

26. О работе историков-марксистов в провинции // Историк-марксист. - 1931. - № 21. - С. 136-139.

27. Очерки истории исторической науки в CCCP. T. IV. - M. : Наука, 1966. - 856 с.
28. Письмо Западно-Сибирского отделения Общества историков-марксистов от 28 декабря 1932 г. // АРАН. - Ф. 377. - ОП. 1. - Д. 75. - Л. 29.

29. Письмо Кнорина в Президиум Общества историков-марксистов 29 июля 1932 г. // АРАН. Ф. 377. - Оп. 1. - Д. 74. - Л. 185.

30. Письмо Комитета по заведыванию учеными и учебными заведениями ЦИК СССР от 29 октября 1932 г. // АРАН. - Ф. 377. - Оп. 1. - Д. 75. - Л. 6.

31. Письмо комитета по заведыванию учеными и учебными заведениями ЦИК СССР от 15 января 1933 г. // АРАН. - Ф. 377. - ОП. 1. - Д. 75. - Л. 32.

32. Письмо от председателя Общества историков-марксистов Центрально-Черноземной области от 1 августа 1932 г. // АРАН. - Ф. 377. - Оп. 1. Д. 74. - Л. 193-194.

33. Письмо отделениям и ячейкам содействия общества историков-марксистов от 8 июня 1932 г. // АРАН. - Ф. 377. - Оп. 1. - Д. 225. - Л. 15-16.

34. Письмо ученого секретаря ЛОИМ Пригожина // АРАН. - Ф. 377. - Оп. 1. - Д. 74. - Л. 75.

35. Покровский, М. Н. «Новые» течения в русской исторической литературе / М. Н. Покровский // Историк-марксист. - 1928. - № 7. - С. 3-17.

36. Покровский, М. Н. Очередные задачи историков-марксистов (доклад на общем собрании Общества 19.03.1930 г.) / М.Н.Покровский // Историк-марксист. - 1930. - № 16. - С. 3-19.

37. Постановление ЦК ВКП(б) по докладу президиума Коммунистической академии. 15 марта 1931 г. // Вестник Коммунистической академии. 1931. -№ 2-3. - С. 3-5.

38. Протокол заседания бригады по перестройки работы Общества историков-марксистов от 19 апреля 1932 г. // АРАН. - Ф. 377. - Оп. 1. - Д. 252. - Л. 1-2.

39. Протокол заседания президиума Общества историков-марксистов от 27 марта 1932 г. // АРАН. Ф. 377. - Оп. 1. - Д. 249. - Л. 7-10.

40. Протокол заседания Президиума Общества историков-марксистов от 7 июня 1932 г. // АРАН. Ф. 377. - Оп. 1. - Д. 249. - Л. 1-3.

41. Резолюции, принятые на общем собрании Общества историков-марксистов от 19.ІІІ.30 г. // Историк-марксист. - 1930. - № 15. - С. 165-167.

42. Справка о Татарове // АРАН. - Ф. 377. Оп. 1. - Д. 225. - Л. 9-9 об.

43. Стенограмма совещания в президиуме Коммунистической академии 31 августа 1932 г. // АРАН. - Ф. 350. - Оп. 1. - Д. 645. - Л. 2-20.

44. Стенограмма совещания обществ, состоящих при Президиуме и институтах Коммунистической академии 15 мая 1932 г. // АРАН. - Ф. 350. Оп. 1. - Д. 748. - Л. 1-29.

45. Стецкий, А. О научной работе Комакадемии / А. Стецкий // Вестник Коммунистической академии. - 1931. - № 2-3. - С. 6-17. 
46. Трибуна читателя // Борьба классов. 1934. - № 9. - С. 101-102.

\section{REFERENCES}

1. Akademik P.O. Gorin. Dokumenty i materialy [Academician P.O. Gorin. Documents i Materialy]. Minsk, Beloruskaja navuka Publ., 2011.347 p.

2. Alatorceva A.I. Sovetskaja istoricheskaja nauka na perelome 20-30-h godov [Soviet Historical Science at the Turning Point of the 20-30s]. Istorija $i$ stalinizm [History and Stalinism]. Moscow, Politizdat Publ., 1991, pp. 248-283.

3. Artizov A.N. Pokrovskij: final kar'ery-uspeh ili porazhenie? [Pokrovsky: Career Finale-Success or Failure?]. Otechestvennaja istorija [National History]. 1998, no. 1, pp. 77-96.

4. $\mathrm{V}$ obshhestve istorikov-marksistov [The Society of Historians-Marxists]. Bor'ba klassov [Class Struggle], 1931, no. 2, p. 135.

5. Vlast' $i$ hudozhestvennaja intelligencija. Dokumenty CK RKP(b) - VKP(b), VChK - OGPUNKVD o kul'turnoj politike. 1917-1953 [The Authority and the Artistic Intelligentsia. Documents of the Central Committee of the RCP(b) - VKP(b), Cheka-OGPU-NKVD on Cultural Policy. 1917-1953]. Moscow, Mezhdunarodnyj fond «Demokratija» Publ., $1999.868 \mathrm{p}$.

6. V prezidium Kommunisticheskoj akademii. Pis'mo M.N. Pokrovskogo [To the Presidium of the Communist Academy. Letter From M.N. Pokrovsky]. Arhiv Rossijskoj akademii nauk [Archive of the Russian Academy of Sciences], f. 377, op. 1, d. 261, 1. 20-20 revs.

7. V prezidiume Komakademii [The Presidium of the Communist Academy]. Vestnik Kommunisticheskoj akademii [Bulletin of the Communist Academy], 1931, no. 5-6, pp. 126-127.

8. Vsem otdelenijam obshhestva istorikovmarksistov [All Branches of the Society of Marxist Historians]. Bor'ba klassov [Class Struggle], 1932, no. 2-3, p. 136.

9. Vystuplenie H.G. Lur'e na soveshhanii obshhestv, sostojashhih pri Komakademii 5 maja 1932 g. [Speech by H.G. Lurie at the Meeting of the Societies, Held in the Communist Academy on 5 May]. Arhiv Rossijskoj akademii nauk [Archive of the Russian Academy of Sciences], f. 350, op. 1, d. 748, 1. $18-22$.

10. Danilov V.N. Obshhestvo istorikovmarksistov i istoriki «staroj shkoly» [The Society of Marxist Historians and of the "Old School" Historians]. Istorija i istoricheskaja pamjat' [History and Historical Memory]. Saratov, Sarat. gos. un-t, 2016, no. 13-14, pp. 93-103.
11. Disput o knige D.M. Petrushevskogo: (O nekotoryh predrassudkah i sueverijah v istoricheskoj nauke) [Debate About the Book of D.M. Petrushevsky (About Some Prejudices and Superstitions in Historical Science)]. Istorik-marksist [Marxist Historian], 1928, no. 8, pp. 79-116.

12. Doklad Gorina P.O. na I Vsesojuznoj konferencii istorikov-marksistov [Report of Gorin P.O. at the First All-Union Conference of Marxist Historians]. Istorik-marksist [Marxist Historian], 1929, no. 11, pp. 218-228.

13. Doroshenko V.A. Obrazovanie i osnovnye jetapy dejatel'nosti Obshhestva istorikov-marksistov (1925-1932 gg.) [Formation and Main Stages of the Society of Marxist Historians (1925-1932)]. Vestnik Moskovskogo universiteta [Bulletin of Moscow University]. Series IX. History. 1966, no. 3, pp. 10-22.

14. Dunaevskij V.A. O pis'me Stalina v redakciju zhurnala «Proletarskaja revoljucija» $\mathrm{i}$ ego vozdejstvie na nauku i sud'by ljudej [About Stalin's Letter to the Editor of "The Proletarian Revolution" Magazine and its Impact on Science and the Fate of People]. Istorija $i$ stalinizm [History and Stalinism]. Moscow, Politizdat Publ., 1991, pp. 284-297.

15. Zhemchuzhina L. Kak proshel v Moskve jubilej Karla Marksa [As was Held in Moscow on the Anniversary of Karl Marx]. Bor'ba klassov [Class Struggle], 1933, no. 5, pp. 119-120.

16. Zasedanie orgkomiteta po sozyvu plenuma O-va istorikov-marksistov ot 20 aprelja $1932 \mathrm{~g}$. [Meeting of the Organizing Committee for the Convocation of the Plenum of the Marxist Historians On April 20, 1932]. Arhiv Rossijskoj akademii nauk [Archive of the Russian Academy of Sciences], f. 377, op. 1, d. 251,1. 1-2.

17. Zaharova M. V obshhestve istorikovmarksistov [In the Society of Marxist Historians]. Bor'ba klassov [Class Struggle], 1931, no. 6-7, p. 159.

18. Istoriografija istorii SSSR (jepoha socializma) [Historiography of the History of the USSR (the Era of Socialism)]. Moscow, Vyssh. Sh. Publ., 1982. 336 p.

19. Kak rabotaet obshhestvo istorikovmarksistov [How the Society of Marxist Historians Works]. Bor'ba klassov [Class Struggle], 1931, no. 1, pp. 108-110.

20. Korzhihina T.P. Izvol'te byt'blagonadezhny! [Please be Trustworthy!]. Moscow, Rossijsk. gos. gumanit. un-t Publ., 1997.372 p.

21. Kujpajgorodskaja A.P., Lebina N.B. Dobrovol'nye obshhestva Petrograda-Leningrada v 1917-1937 gg. (tendencii razvitija) [Voluntary Societies of Petrograd-Leningrad in 1917-1937 (Development Trend)]. Dobrovol'nye obshhestva v PetrogradeLeningrade v 1917-1937 gg. [Voluntary Societies in Petrograd-Leningrad in 1917-1937]. Leningrad, Nauka Publ., 1989, pp. 5-17. 
22. Makarenko P.V. Pis'mo Stalina v redakciju zhurnala «Proletarskaja revoljucija» i ego posledstvija dlja istoricheskoj nauki [Stalin's Letter to the Editor of "The Proletarian Revolution" and Its Consequences for Historical Science]. Chvikalova I.M., prof., ed. Aktual'nye problemy social'no-gumanitarnyh nauk mezhvuzovskij sbornik nauchnyh trudov [Actual Problems of Social and Humanitarian Sciences Intercollegiate Collection of Scientific Works. Edited by: Professor I.M. Chikalova]. Voronezh, Voronezh. gos. lesotekh. Akad., 1997, pp. 45-47.

23. Metel' O.V. Institut istorii Kommunisticheskoj Akademii v otrazhenii dokumental'nyh svidetel'stv [Institute of History of the Communist Academy in the Reflection of Documentary Evidence]. Mir istorika: istoriogr. sb. [The World of the Historian: A Historiographical Collection]. Omsk, Izd-vo Omsk. gosud. un-ta, 2017, pp. 419-430.

24. Metel' O.V. Sozdanie seti regional'nyh otdelenij Obshhestva istorikov-marksistov v 1930$1932 \mathrm{gg}$. [Creation of a Network of Regional Branches of the Society of Marxist Historians in 1930-1932]. Magistra Vitae: jelektron. zhurn. po ist. naukam $i$ arheologii [Magistra Vitae: Electronic Journal of Historical Sciences and Archaeology], 2018, no. 1, pp. 213-219.

25. O zadachah marksistskoj istoricheskoj nauki v rekonstruktivnyj period. Tezisy frakcii soveta Obshhestva istorikov-marksistov [On the Tasks of Marxist Historical Science in the Reconstructive Period. Theses of the Faction of the Council of the Society of Marxist Historians]. Istorik-marksist [Marxist Historian], 1931, no. 21, pp. 8-17.

26. O rabote istorikov-marksistov v provincii [On the Work of Marxist Historians in the Provinces]. Istorik-marksist [Marxist Historian], 1931, no. 21, pp. 136-139.

27. Ocherki istorii istoricheskoj nauki v SSSR. T. $I V$ [Essays on the History of Historical Science in the USSR. Vol. IV]. Moscow, Nauka Publ., 1966. 856 p.

28. Pis'mo Zapadno-Sibirskogo otdelenija Obshhestva istorikov-marksistov ot 28 dekabrja 1932 g. [Letter of the West Siberian Branch of the Society of Marxist Historians Dated December 28, 1932]. Arhiv Rossijskoj akademii nauk [Archive of the Russian Academy of Sciences], f. 377, op. 1, d. 75, 1.29.

29. Pis'mo Knorina v Prezidium Obshhestva istorikov-marksistov 29 ijulja 1932 g. [Knorin's Letter to the Presidium of the Society of Marxist Historians, July 29, 1932]. Arhiv Rossijskoj akademii nauk [Archive of the Russian Academy of Sciences], f. 377, op. 1, d. 74, 1. 185.

30. Pis'mo Komiteta po zavedyvaniju uchenymi i uchebnymi zavedenijami CIK SSSR ot 29 oktjabrja 1932 g. [Letter of the Committee for the Management of Scientific and Educational Institutions of the CEC of the USSR Dated October 29, 1932]. Arhiv Rossijskoj akademii nauk [Archive of the Russian Academy of Sciences], f. 377, op. 1, d. 75, 1. 6.

31. Pis'mo komiteta po zavedyvaniju uchenymi i uchebnymi zavedenijami CIK SSSR ot 15 janvarja 1933 g. [Letter of the Committee for the Management of Scientific and Educational Institutions of the CEC of the USSR Dated January 15, 1933]. Arhiv Rossijskoj akademii nauk [Archive of the Russian Academy of Sciences], f. 377, op. 1, d. 75, 1. 32.

32. Pis'mo ot predsedatelja Obshhestva istorikov-marksistov Central'no-Chernozemnoj oblasti ot 1 avgusta $1932 \mathrm{~g}$. [Letter from the Chairman of the Society of Marxist Historians of the Central Chernozem Region Dated August 1, 1932]. Arhiv Rossijskoj akademii nauk [Archive of the Russian Academy of Sciences], f. 377, op. 1, d. 74, 1. 193-194.

33. Pis'mo otdelenijam i jachejkam sodejstvija obshhestva istorikov-marksistov ot 8 ijunja $1932 \mathrm{~g}$. [Letter to the Branches and Support Cells of the Society of Marxist Historians Dated June 8, 1932]. Arhiv Rossijskoj akademii nauk [Archive of the Russian Academy of Sciences], f. 377, op. 1, d. 225, 1. 15-16.

34. Pis'mo uchenogo sekretarja LOIM Prigozhina [Letter from the Scientific Secretary LOIM Prigogine]. Arhiv Rossijskoj akademii nauk [Archive of the Russian Academy of Sciences], f. 377, op. 1, d. 74, 1. 75.

35. Pokrovskij M.N. «Novye» techenija v russkoj istoricheskoj literature ["New" Trends in Russian Historical Literature]. Istorik-marksist [Marxist Historian], 1928, no. 7, pp. 3-17.

36. Pokrovskij M.N. Ocherednye zadachi istorikov-marksistov (doklad na obshhem sobranii Obshhestva 19.03.1930 g.) [The Next Tasks of Marxist Historians (Report at the General Meeting of the Society 19.03.1930)]. Istorik-marksist [Marxist Historian], 1930, no. 16, pp. 3-19.

37. Postanovlenie CK VKP(b) po dokladu prezidiuma Kommunisticheskoj akademii. 15 marta 1931 g. [Resolution of the Central Committee of the CPSU(b) on the Report of the Presidium of the Communist Academy. March 15, 1931]. Vestnik Kommunisticheskoj akademii [Bulletin of the Communist Academy], 1931, no. 2-3, pp. 3-5.

38. Protokol zasedanija brigady po perestrojki raboty Obshhestva istorikov-marksistov ot 19 aprelja 1932 g. [Minutes of the Meeting of the Brigade for Perestroika of the Society of Marxist Historians, April 19, 1932]. Arhiv Rossijskoj akademii nauk [Archive of the Russian Academy of Sciences], f. 377, op. 1, d. 252,1. 1-2.

39. Protokol zasedanija prezidiuma Obshhestva istorikov-marksistov ot 27 marta $1932 \mathrm{~g}$. [Minutes of the Meeting of the Presidium of the Society of Marxist Historians of March 27, 1932]. Arhiv Rossijskoj 


\section{СОВЕТСКАЯ ВЛАСТЬ В 1920-х - ПЕРВОЙ ПОЛОВИНЕ 1930-х ГГ.}

akademii nauk [Archive of the Russian Academy of Sciences], f. 377, op. 1, d. 249, 1. 7-10.

40. Protokol zasedanija Prezidiuma Obshhestva istorikov-marksistov ot 7 ijunja $1932 \mathrm{~g}$. [Minutes of the Meeting of the Presidium of the Society of Marxist Historians of June 7, 1932]. Arhiv Rossijskoj akademii nauk [Archive of the Russian Academy of Sciences], f. 377, op. 1, d. 249, 1. 1-3.

41. Rezoljucii, prijatye na obshhem sobranii Obshhestva istorikov-marksistov ot 19.III.30 g. [Resolutions Adopted at the General Meeting of the Society of Marxist Historians of 19.III.30]. Istorikmarksist [Marxist Historian], 1930, no. 15, pp. 165-167.

42. Spravka o Tatarove [Information About Tatarov]. Arhiv Rossijskoj akademii nauk [Archive of the Russian Academy of Sciences], f. 377, op. 1, d. 225, 1. 9-9 revs.

43. Stenogramma soveshhanija $v$ prezidiume Kommunisticheskoj akademii 31 avgusta 1932 g.
[Transcript of the Meeting at the Presidium of the Communist Academy on August 31, 1932]. Arhiv Rossijskoj akademii nauk [Archive of the Russian Academy of Sciences], f. 350, op. 1, d. 645, 1. 2-20. 44. Stenogramma soveshhanija obshhestv, sostojashhih pri Prezidiume i institutah Kommunisticheskoj akademii 15 maja 1932 g. [Transcript of the Meeting of the Societies Attached to the Presidium and Institutes of the Communist Academy on May 15, 1932]. Arhiv Rossijskoj akademii nauk [Archive of the Russian Academy of Sciences], f. 350, op. 1, d. 748, 1. 1-29.

45. Steckij A. O nauchnoj rabote Komakademii [About the Scientific Work of the Communist Academy]. Vestnik Kommunisticheskoj akademii [Bulletin of the Communist Academy], 1931, no. 2-3, pp. 6-17.

46. Tribuna chitatelja [Reader's Tribune]. Bor'ba klassov [Class Struggle], 1934, no. 9, pp. 101-102.

\section{Information About the Author}

Victor N. Danilov, Doctor of Sciences (History), Professor, Head of the Department of the Russian History and Historiography, Institute of History and International Relations, N.G. Chernyshevskiy Saratov State University, Astrakhanskaya St, 83, 410012 Saratov, Russian Federation, danilovvik@yandex.ru, https://orcid.org/0000-0003-2080-7736

\section{Информация об авторе}

Виктор Николаевич Данилов, доктор исторических наук, профессор, заведующий кафедрой отечественной истории и историографии, Институт истории и международных отношений, Саратовский государственный университет им. Н.Г. Чернышевского, ул. Астраханская, 83, 410012 г. Саратов, Российская Федерация, danilovvik@yandex.ru, https://orcid.org/0000-0003-2080-7736 